\title{
IMPLEMENTATION OF BALANCED SCORECARD IN SPA COMPANY
}

\author{
[Implementácia metódy balanced scorecard v kúpel'nom podniku] \\ Anna Šenková ${ }^{1}$, Radka Lúchavová $^{2}$ \\ ${ }^{1}$ Prešovská univerzita v Prešove, Fakulta manažmentu, Konštantínova 16, 08001 Prešov \\ Email:anna.senkova@unipo.sk \\ ${ }^{2}$ Prešovská univerzita v Prešove, Fakulta manažmentu, Konštantínova 16, 08001 Prešov \\ Email:1radus11@gmail.com
}

\begin{abstract}
Modern way of strategic management, which puts emphasis also on financial and nonfinancial indicators to measure business performance is the Balanced Scorecard. The instability of the economic environment requires the implementation of the strategy where the critical factors do affect business performance. The aim of this paper is to present the possibilities of application this modern method in the condition of the spa company in the northeast of the Slovakia.
\end{abstract}

Keywords: balanced scorecard, Slovakia, spa company, strategic management.

JEL classification: J53, M12, M14

Doručeno redakci: 2.5.2018; Recenzováno: 17.5.2018; 22.8.2018; Schváleno k publikování: 21.11.2018

\section{Úvod do problematiky}

Slovensko patrí medzi najvyspelejšie európske krajiny v oblasti kúpel'níctva s najväčším počtom kúpel'ných miest v strednej Európe. V súčasnosti ich je 21 a podnikatel'skú činnost' v nich vykonáva 30 kúpel'ných podnikov. Vysoká úroveň kúpel'níckych služieb na Slovensku vychádza najmä z tradície, vysokej profesionality pracovníkov, ale aj legislatívy, ktorá určuje minimálne požiadavky na personál a vybavenie. Dlhé roky boli totiž slovenské kúpele budované ako produkt so silným medicínskym zázemím, ktorý sa darí exportovat' do zahraničia (Eliašová 2009). Ani tie najlepšie prírodné podmienky však nezaistia rozvoj kúpel'níctva a kúpel'ného cestovného ruchu $\mathrm{v}$ budúcnosti Rozhodujúce je $\mathrm{v}$ súčasnom konkurenčnom prostredí presadit' sa na trhu a vytvorit' si dobré meno. Na dosiahnutie ekonomických ciel'ov kúpených miest je potrebná kooperácia zainteresovaných subjektov, kúpel'ný región musí vystupovat' ako celok a ponúkat' služby pre konkrétny trhový segment. Tomu je potrebné prispôsobit' všetky marketingové aktivity a využívat' moderné spôsoby a metódy strategického riadenia podniku. Jednou z možností je aplikácia koncepcie Balanced Scorecard (d’alej BSC), ktorá je známa od 90-tych rokov 20. storočia. Pôvodne vznikla ako rámec pre meranie výkonnosti podniku, ale vel'mi rýchlo sa zmenila na strategický nástroj riadenia výkonnosti (Grasseová 2012).

\section{Podstata metódy Balanced Scorecard}

Jej podstata vychádza z potrieb zákazníkov a na nich nadväzujúcich potrieb podniku, pričom musí prihliadat' na schopnost' reakcie podniku na zmeny v jeho okolí. Zavedenie BSC v podniku znamená, že sa ciele, meradlá, ciel’ové hodnoty a strategické akcie priradzujú jednotlivým perspektívam - finančnej, zákazníckej, perspektíve interných procesov a perspektíve učenia sa a rastu. Ak sú správne zvolené ciele a meradlá, môže táto stratégia nielen objasnit' strategické smerovanie podniku, ale súbežne ho zvládne aj zmerat'. Podstatou finančnej perspektívy je sledovanie spokojnosti vlastníkov, uspokojovanie ich záujmov v podobe zhodnocovania vložených prostriedkov. BSC zachováva finančnú perspektívu, pretože 
finančné ukazovatele sú dôležité pre hodnotenie ekonomických dôsledkov realizovaných akcií. Je dôležité, aby všetky ciele ostatných perspektív metódy BSC boli prepojené k dosahovaniu jedného alebo viac ciel'ov finančnej perspektívy. Toto prepojenie $\mathrm{k}$ finančným ciel'om vyjadruje, že tvorba hodnoty a uspokojenia vlastníkov je dlhodobým ciel'om podniku. Kl'účovým ciel’om finančnej perspektívy môže byt' napr. rentabilita vlastného kapitálu, prevádzkový zisk a d’alšie (Pavelková, Knapková 2005). Zákaznícka perspektíva sa zameriava na vstup podniku na trh a jeho umiestnením, výberom zákazníkov a orientáciou na nich. Zákazníci predstavujú pre podnik tržby, a práve preto by im mal podnik venovat' vel'kú pozornost'. V tejto perspektíve je dôležité transformovat' strategické poslanie podniku do konkrétnych, tržne a zákaznícky orientovaných ciel'ov. Kl'účové výstupné meradlá zákazníckej perspektívy zvyčajne zahrňujú: lojalitu zákazníkov, získavanie nových zákazníkov, spokojnost' zákazníkov a ich ziskovost', podiel na trhu a tržbách. Je vhodné, ak sú v meradlách zákazníckej perspektívy BSC zahrnuté aj meradlá pre hodnotové výhody. Tieto výhody môže podnik poskytnút' svojim zákazníkom. Práve hodnotové výhody predstavujú vlastnosti výrobku či služby, ktorými si podniky budujú lojalitu a spokojnost' svojich zákazníkov. Podl'a Kaplana a Nortona (2007), existujú tri kategórie hodnotových výhod, ktoré platia pre všetky odvetvia, a to:

- vlastnosti výrobku/služby - funkčnost', kvalita a cena,

- vzt’ahy so zákazníkom - skúsenosti s nákupom a osobný vzt’ah,

- imidž a povest' podniku.

Manažéri by prieskumom mali zistit', čo zákazníci v ciel’ových segmentoch oceňujú a podl'a toho zvolit' vhodnú hodnotovú výhodu (Kaplan, Norton 2007).

Perspektíva interných procesov zist'uje kritické procesy, v ktorých podnik musí dosahovat' excelentné výsledky. Táto perspektíva BSC je kl'účová pre dosahovanie úspechu. Posudzuje ako rýchlo, kvalitne a s akými nákladmi je podnik schopný zaist'ovat' svoje aktivity, činnost' a procesy. Jednotlivé meradlá perspektívy interných procesov sa zaoberajú prístupmi, ktoré majú najväčší vplyv na spokojnost' zákazníkov a na dosiahnutie finančných ciel'ov (Král 2010). Pri tvorbe BSC zvyčajne finančná a zákaznícka perspektíva, ako aj perspektíva interných procesov odhalia vel'ké rozdiely medzi požadovanou predstavou a skutočnou realitou. Schopnost' l'udí, systémov a procedúr často krát nie sú dostatočné na to, aby sa výkonnost' podniku zvyšovala. Aby podnik rozdiely odstránil, musí investovat' do rekvalifikácie zamestnancov, zdokonal'ovat' podnikové procedúry a rutinné postupy, zlepšovat' informačné technológie a systémy. Práve tieto ciele si kladie perspektíva učenia sa a rastu (Kaplan, Norton 2007).

Tabul'ka 1: Meradlá nastavené pre jednotlivé oblasti perspektív BSC

\begin{tabular}{|l|l|l|l|}
\hline Finančná perspektíva & Zákaznícka perspektíva & Interné procesy & Učenie sa \\
\hline Zníženie nákladov & Podiel na trhu & Zlepšenie zdrojov & Počet nových produktov \\
\hline Obeh hotovosti & Počet stažností & Zníženie strát & Školenie zamestnancov \\
\hline Rast príjmov & Spokojnost' zákazníkov & $\begin{array}{l}\text { Vyššia morálka } \\
\text { a spokojnost' zamestnancov }\end{array}$ & $\begin{array}{l}\text { Dížka a výstupy z školenia } \\
\text { zamestnancov }\end{array}$ \\
\hline Rast marží & $\begin{array}{l}\text { Dodacie lehoty - rýchlost' } \\
\text { vybavenia }\end{array}$ & Predaj na zamestnanca & Nadobudnuté zručnosti \\
\hline
\end{tabular}

Zdroj: Kourdi 2011

Koncepcia BSC je podnikmi považovaná za vel'mi prínosnú. Existuje však niekol'ko bariér a obmedzení, ktoré bránia jej úspešnej implementácií. Medzi tieto bariéry patria bariéry vízie, bariéry zdrojov, l’udská bariéra či bariéra riadenia. Ďalšími možnými zdrojmi neúspechu sú napr. problém vybrat' správne meradlá, prevzatie architektúry stratégie od iných subjektov, neprispôsobenie BSC stratégií podniku, nevytvorenie strategickej mapy, neaktualizovanie BSC 
pri zmenách vonkajšieho či vnútorného prostredia alebo chýbajúca softwarová podpora (Grasseová 2010).

Táto koncepcia sa často stáva predmetom výskumov súvisiacich s jej využívaním a overovaním ako metódy na meranie a riadenie výkonnosti podniku. Spoločnost' Bain \& Company každoročne realizuje výskumy v oblasti strategického manažmentu pod ktorý spadá aj koncepcia BSC. Spomínaná koncepcia sa pravidelne umiestňuje v prvej desiatke najpoužívanejších manažérskych nástrojov. Výskum spoločnosti Bain \& Company z roku 2017, ktorý bol realizovaný na vzorke 1200 podnikov po celom svete priniesol výsledok, že koncepciu BSC používa až 53\% podnikov. Zo všetkých manažérskych nástrojov ju môžeme zaradit' zhruba do polovice z 10 najpoužívanejších nástrojov. Na Slovensku sa zaoberala výskumom BSC Karabašová (2010) v rámci svojej dizertačnej práce. Z jej výskumu realizovaného na vzorke 110 podnikov vyplynulo, že koncepciu BSC využíva len 6\% oslovených podnikov. $\mathrm{V}$ porovnaní s ostatnými krajinami to znamená obrovský rozdiel $\mathrm{v}$ neprospech Slovenska. Autorky Lesákova a Dubcová realizovali výskum v roku 2016 a prišli s novými výsledkami, ktoré však nepriniesli výrazné zmeny. Ich výsledky ukázali, že koncepciu BSC na Slovensku využíva iba $9,15 \%$ podnikov. V porovnaní s vyspelými krajinami vo využívaní BSC Slovensko zastáva, pretože v Európe je jej využívanie na úrovni 53\%, pričom ide hlavne o štáty západnej Európy (Bain\&Company 2017).

\section{Ciel' a metodika skúmania}

Ciel'om predkladaného príspevku je prezentovat' možnosti implementácie Balanced Scorecard do systému riadenia v kúpel'nom podniku Vyšné Ružbachy, a.s., ktorý sa nachádza na severovýchode Slovenska. Vzhl'adom na rozsiahlost' analýzy súčasných spôsobov merania a hodnotenia výkonnosti skúmaného podniku a najmä z dôvodu dôvernosti údajov o súčasnej finančnej situácii a internom prostredí podniku, prezentujeme v podkapitole 4 len vybrané ukazovatele. Svoju pozornost' sústred'ujeme na návrh procesu implementácie BSC. Medzi základné metódy získania spol'ahlivých a dôveryhodných informačných zdrojov patrili interview s manažérkou obchodu a marketingu kúpel'ov, terénny prieskum priamo na mieste a pozorovanie. Sekundárne dáta na spracovanie finančnej analýzy a zistenia ukazovatel’ov likvidity, rentability, aktivity, stability, výkonnosti a hodnoty podniku boli získané z výkazov o účtovnej uzávierke z rokov 2015 a 2016.

\section{Analýza súčasného stavu}

Vyšné Ružbachy sa nachádzajú v najzdravšom regióne Slovenska, na severovýchode Spiša, na južných svahoch Vysokých Tatier. Bezkonkurenčnou výhodou kúpel'ov vo Vyšných Ružbachoch je prírodný liečivý zdroj a prostredie v ktorom sa nachádzajú. Oblast' Zamaguria a konkrétne hranica medzi dvomi národnými parkami Slovenska - Tatranským národným parkom a Národným parkom Pieniny, je najčistejšia oblast' na Slovensku. Ovzdušie, aké sa nachádza práve v regióne Kúpel’ov Vyšné Ružbachy inde nenájdeme, a práve tento faktor je vel'kou konkurenčnou výhodou z hl'adiska rovnakosti.

Mocné liečivé termálne pramene oddávna uzdravujú telo a atmosféra okolitej prírody upokojuje dušu. Príroda obdarila kúpele vzácnym darom v podzemí - liečivou vodou, ktorá sa prediera v podobe 14 minerálnych termálnych prameňov na zemský povrch a dáva možnost' liečit' a regenerovat' psychické a fyzické sily. Kúpele, známe termálnym kúpaliskom a travertínovým jazierkom Kráter o priemere $20 \mathrm{~m} \mathrm{~s}$ termálnou vodou $23{ }^{\circ} \mathrm{C}$, ponúkajú predovšetkým hydrouhličitano-síranové, vápenato-horečnaté, hydrouhličité pramene a povzbudivé klimatické podmienky. Pramene spolu s komplexnou zdravotnou starostlivost'ou a nadštandardnými službami vytvárajú oázu zdravia. Význam a liečivé účinky minerálnych prameňov predurčuje 
aj samotný názov kúpel’ov Vyšné Ružbachy - „Rauschenbach“ - šumivý potok. Medzi základné indikácie kúpel'ov Vyšné Ružbachy patria onkologické ochorenia, choroby obehového ústrojenstva, choroby tráviaceho ústrojenstva, metabolické poruchy, netuberkulózne choroby dýchacích ciest, choroby pohybového ústrojenstva, choroby obličiek a močových ciest, duševné choroby, ženské choroby a choroby z povolania. Najmä v liečbe duševných ochorení nemajú konkurenciu, ked’že liečia aj vel'mi t’ažké stavy.

\subsection{Segmentácia produktov (pobytov)}

Kúpel’ný podnik Kúpele Vyšné Ružbachy, a.s. má širokú škálu poskytovaných pobytov. Pobyty sú rozdelené na tri základné skupiny - liečebné, rekondičné, wellness a dovolenkové. Každá z týchto troch skupín ma niekol'ko podskupín. K liečebným pobytom patria: relax pobyt, senior pobyt, liečebný špeciál, komplexný liečebný pobyt, zdravý pedagóg, ambulantný balík, medical pobyt, jednota dôchodcov. Rekondičné pobyty v podniku Kúpele Vyšné Ružbachy, a.s. zahrňujú komplexnú liečebno-rehabilitačnú a preventívnu starostlivost', 24-hodinovú službu lekára a zdravotnej sestry na JIS, ubytovanie, stravovanie, širokú ponuku športových a kultúrno-spoločenských aktivít. Wellness a dovolenkové pobyty sa sústred'ujú na ponuku víkendu s procedúrami, wellness pobyt a v zimnom období produkt super lyžovačka.

Tabul'ka 2: Štruktúra dopytu po produktoch kúpel'ného podniku v období rokov 2012 - 2016

\begin{tabular}{|l|r|r|r|r|r|}
\hline Pobyt/Rok & 2012 & 2013 & 2014 & 2015 & 2016 \\
\hline Liečebný & 558 & 816 & 987 & 1150 & 2304 \\
\hline Relaxačný & 303 & 366 & 278 & 333 & 525 \\
\hline Wellness & 1799 & 3550 & 4251 & 3357 & 3077 \\
\hline Seniorský & 576 & 344 & 324 & 513 & 582 \\
\hline Rodinný & 743 & 929 & 682 & 697 & 977 \\
\hline
\end{tabular}

Zdroj: vlastné spracovanie na základe interných materiálov Kúpel’ov Vyšné Ružbachy a.s.

Odrážajúc životný štýl dnešných l'udí stúpa počet liečebných pobytov a relaxačných pobytov. To znamená, že pribúda chorých l'udí, no aj l'udí, ktorí chcú preventívne zabránit' ochoreniam práve formou relaxačných pobytov v kúpel'och. Wellness pobytov bolo najviac v roku 2014, kedy nastal boom vo wellness a zdravom životnom štýle a počet týchto pobytov postupne klesá. Seniorských a rodinných pobytov celkovo pribúda.

\subsection{Segmentácia zákazníkov}

Zákazníci kúpel’ov sú rozdelení do 4 základných skupín. Skupinou, ktorá najviac potrebuje kúpel'né služby sú pacienti po akútnom zákroku, ktorým pobyt plne hradí zdravotná poist'ovňa. Ďalšou skupinou sú rekondiční pacienti. Rekondičné pobyty sú určené zamestnancom, ktorí vykonávajú vybrané povolania spĺňajúce kritériá st’ažených pracovných podmienok - l'udia, ktorí pracujú v nebezpečnom prostredí, kde je vel'ký hluk, vel'mi sa práši, l'udia, ktorí sú vystavení pôsobeniu chemických látok, a súčasne spĺn̆ajú podmienky účelnosti rekondičného pobytu z hl'adiska prevencie profesijného poškodenia zdravia. Dĺžka rekondičného pobytu je najmenej jeden týždeň, optimum dva týždne. (v zmysle Zákona č 124/2006 Z. z. o bezpečnosti a ochrane zdravia pri práci, $\S 11$ Rekondičné pobyty). Tomuto typu klientov pobyt hradí zamestnávatel' raz za 3 roky. Medzi túto kategóriu kúpel'ných klientov v Kúpel'och Vyšné Ružbachy, a.s. patria zamestnanci U. S. Steel Košice alebo Železníc SR. Tret'ou skupinou zákazníkov sú samoplatitelia označovaní ako komerční. Tí si celý svoj pobyt platia zo svojich zdrojov a samovol'ne sa rozhodujú kúpele navštívit'. Informácie o pobytoch a poskytovaných službách nachádzajú pomocou webovej stránky kúpel'ov, na facebooku a iných sociálnych siet’ach, cez cestovné kancelárie a agentúry ako aj na zl'avových portáloch. Poslednou skupinou zákazníkov, ktorí využívajú kúpel’né služby sú zahraniční klienti. 
Tabul'ka 3: Počet zákazníkov v rokoch 2015 a 2016

\begin{tabular}{|l|r|r|}
\hline Typ zákazníkov/Rok & 2015 & 2016 \\
\hline Pacienti & 1311 & 1312 \\
\hline Rekondičné pobyty & 2196 & 3189 \\
\hline Komerčné pobyty & 10100 & 10386 \\
\hline Spolu & 13607 & 14887 \\
\hline
\end{tabular}

Zdroj: vlastné spracovanie na základe výročných správ Kúpel'ov Vyšné Ružbachy a.s.

Dôležitým ukazovatel'om je nielen počet návštevníkov, ale dížka ich pobytu, t.j. počet prenocovaní, ktorý sa z roka na rok zvyšuje u všetkých skupín. Práve vd'aka tomu sa zvyšuje aj zisk podniku. Najviac zákazníkov a prenocovaní tvoria práve komerční klienti, ktorí si sami hradia pobyt a to je pre kúpele výhodné (Tabul'ka 4).

Tabul'ka 4: Počet prenocovaní v rokoch 2012 - 2016

\begin{tabular}{|l|r|r|r|r|r|}
\hline $\begin{array}{c}\text { Typ } \\
\text { zákazníkov/Rok }\end{array}$ & $\mathbf{2 0 1 2}$ & $\mathbf{2 0 1 3}$ & $\mathbf{2 0 1 4}$ & $\mathbf{2 0 1 5}$ & $\mathbf{2 0 1 6}$ \\
\hline Pacienti & 33093 & 19299 & 22750 & 28355 & 28188 \\
\hline Rekondičné pobyty & 2924 & 19101 & 32986 & 24184 & 21202 \\
\hline Komerčné pobyty & 26612 & 33338 & 32901 & 32943 & 37412 \\
\hline Spolu & 62629 & 71738 & 88637 & 85482 & 86802 \\
\hline
\end{tabular}

Zdroj: vlastné spracovanie na základe výročných správ Kúpel’ov Vyšné Ružbachy a.s.

Tabul'ka 5: Štruktúra návštevnosti kúpel’ného podniku v období rokov 2012 - 2016

\begin{tabular}{|l|r|r|r|r|r|}
\hline \multicolumn{1}{|c|}{ Typ zákazníka/Rok } & $\mathbf{2 0 1 2}$ & $\mathbf{2 0 1 3}$ & $\mathbf{2 0 1 4}$ & $\mathbf{2 0 1 5}$ & $\mathbf{2 0 1 6}$ \\
\hline Domáci & 6896 & 9675 & 12322 & 11733 & 12936 \\
\hline Zahraniční & 2188 & 2676 & 2048 & 1874 & 1953 \\
\hline Spolu & 9084 & 12351 & 14370 & 13607 & 14899 \\
\hline $\begin{array}{l}\text { Podiel zahraničných na } \\
\text { celkovom počte }\end{array}$ & $24,09 \%$ & $21,67 \%$ & $14,25 \%$ & $13,77 \%$ & $13,11 \%$ \\
\hline
\end{tabular}

Zdroj: vlastné spracovanie na základe výročných správ Kúpel'ov Vyšné Ružbachy a.s.

\section{Implementácia metódy Balanced Scorecard}

Prvou fázou pri implementácií konceptu BSC je vytvorenie organizačných predpokladov projektu. V úvode je dôležité samotný koncept popísat' a vytvorit' tím, ktorý bude zodpovedný za jeho realizáciu. Implementáciu metódy BSC je vhodné rozložit' do časového obdobia $4-6$ mesiacov. V koncepte budú použité štyri základné perspektívy - finančná perspektíva, zákaznícka perspektíva, perspektíva interných procesov a perspektívu učenia sa a rastu. Aby bol projekt úspešný, je dôležité pravidelne sledovat' jeho plnenie. Preto je vhodné, aby bol v podniku priebežne, podl'a nášho názoru raz mesačne prediskutovaný aktuálny stav konceptu a plnenia stanovených strategických akcií. Taktiež je dôležité, aby koncept BSC reagoval na vnútorné ako aj vonkajšie zmeny prostredia.

\section{Vymedzenie projektového tímu}

Na základe vykonanej analýzy navrhujeme vedeniu podniku pouvažovat' o zavedení metódy BSC do jeho systému riadenia. Pred samotnou implementáciou je dôležité určit’ projektový tím, ktorý bude zodpovedný za realizáciu projektu. Súčast'ou projektového tímu má byt' vrcholové vedenie podniku; navrhujeme, aby vedúcim projektu bola osoba, ktorá má komplexný prehl'ad o podniku, dokonale pozná jeho ciele a víziu (riaditel'/riaditel'ka podniku). Nakol'ko sa zavedenie BSC dotkne všetkých zamestnancov, pred samotným začiatkom projektu je potrebný „meeting“, ktorého ciel'om je informovat' zamestnancov o projekte, o výhodách a nevýhodách, ktoré z projektu pre nich plynú, oboznámit' ich s postupom implementácie a v neposlednom rade vypočut' si ich názory. Výsledkom školenia by malo byt' pochopenie zmyslu zmeny pre podnik. 


\section{Objasnenie stratégie a tvorba BSC}

Stratégia spoločnosti Kúpele Vyšné Ružbachy, a.s. vychádza z definovanej vízie podniku: „Byt’ úspešný!“ Pre naplnenie vízie je potrebných mnoho krokov a postupov a naplnenie vízie zaberie mnoho času. Navrhujeme podniku prijat' program, ktorý pomôže naplnit' ciele vízie.

Mal by sa zamerat' predovšetkým na:

- skvalitňovanie služieb poskytovaných pacientom, návštevníkom,

- skvalitnenie prostredia, v ktorom sa klienti ako aj pracovníci pohybujú a pracujú,

- konkurencieschopnú výkonnost',

- celkový výsledok hospodárenia,

- vytvorenie modernej organizácie a kvalitnej zamestnaneckej politiky.

Po vyjasnení podnikovej stratégie je d'alším krokom BSC vytvorenie strategických ciel'ov. Následne sa z týchto strategických ciel'ov vytvára strategická mapa príčin, vyberajú meradlá, ktorými možno sledovat' plnenie strategických ciel'ov a určia sa ich postačujúce hodnoty.

\section{Odvodenie strategických ciel'ov}

Samotná tvorba modelu BSC začína stanovením strategických ciel’ov v zvolených perspektívach. Tieto ciele má určit' vrcholové vedenie podniku Kúpele Vyšné Ružbachy, a.s. Prezentované strategické ciele sú návrhom autoriek príspevku. V navrhovanom modeli sme pre každú perspektívu zvolili 3 strategické ciele. Ciele, ktoré vychádzajú z podnikovej stratégie, zo sledovaných ciel'ov a poznatkov získaných analyzovaním jednotlivých perspektív. Všetky ciele smerujú k naplneniu vízie podniku.

\section{Strategické ciele finančnej perspektívy}

$\mathrm{Z}$ finančnej analýzy vyplynulo, že podnik v posledných rokoch hospodári v stratách. Jeho hlavným ciel'om by preto malo byt' dosiahnutie pozitívneho výsledku hospodárenia, a teda sa zo straty dostat' do zisku. Ak bude podnik ziskový, zlepší sa jeho celkový finančný stav a rentabilita bude dosahovat' kladné hodnoty. Aby tomu tak bolo a výsledkom hospodárenia podniku Kúpele Vyšné Ružbachy, a.s. bol zisk, je potrebné splnenie ostatných strategických ciel'ov tejto perspektívy, a to zvýšenie obratu a zníženie nákladov.

Tabul'ka 6: Strategické ciele finančnej perspektívy

\begin{tabular}{|l|l|}
\hline Strategický ciel' & Popis ciel'a \\
\hline F1: Znížit' náklady & $\begin{array}{l}\text { Hl'adat' možnosti vedúce k úspore nákladov, pomocou splnenia ciel'ov v ostatných } \\
\text { perspektívach. }\end{array}$ \\
\hline F2: Zvýšit' obrat & $\begin{array}{l}\text { Zvýšit' tržby spoločnosti zvýšením spokojnosti súčasných zákazníkov a prilákaním } \\
\text { nových zákazníkov. }\end{array}$ \\
\hline $\begin{array}{l}\text { F3: Zlepšit' celkový } \\
\text { finančný stav podniku }\end{array}$ & $\begin{array}{l}\text { Zvy̌šit' rentabilitu podniku a návratnost' cudzieho kapitálu, ktoré negatívne ovplyvňujú } \\
\text { finančnú situáciu podniku pomocou splnenia cielov v ostatných perspektívach. }\end{array}$ \\
\hline
\end{tabular}

Zdroj: vlastné spracovanie

\section{Strategické ciele zákazníckej perspektívy}

Najdôležitejším ciel’om zákazníckej perspektívy je zvyšovanie počtu zákazníkov a ich maximálna spokojnost'. Spokojný zákazník sa rád vráti do kúpel’ov, rád opät' využije komplexné služby v kúpel'och Vyšné Ružbachy, poskytne pozitívnu recenziu on-line alebo známym. Tým podniku zabezpečí pravidelné príjmy, a práve preto je dôležité sledovat' dopyt a potreby zákazníkov. Doterajšia spokojnost' klientely kúpel’ov Vyšné Ružbachy je vysoká, a preto sa v stratégií nemusíme spokojnost'ou príliš zaoberat'. Dôležitejšie je zvyšovanie kvality služieb a získanie nových zákazníkov. 
Tabul'ka 7: Strategické ciele zákazníckej perspektívy

\begin{tabular}{|l|l|}
\hline Strategický ciel' & Popis ciel'a \\
\hline $\begin{array}{l}\text { Z1: Zvýšit' kvalitu poskytovaných služieb a modernizovat' } \\
\text { kúpele }\end{array}$ & $\begin{array}{l}\text { Zvýšit' kvalitu poskytovaných služieb a modernizovat' } \\
\text { kúpele investovaním do modernejš́ch zariadení } \\
\text { a vybavenia kúpel'ov }\end{array}$ \\
\hline Z2: Získat' nových zákazníkov & $\begin{array}{l}\text { Zaistit' rast počtu komerčných klientov - samoplatcov a } \\
\text { tým zvýšit' počet prenocovaní. Zároven si udržat' } \\
\text { súčasných zákazníkov v boji s konkurenciou }\end{array}$ \\
\hline Z3: Rozš́renie on-line marketingových aktivít & Zaviest' on-line reklamu na sociálnych siet'ach \\
\hline
\end{tabular}

Zdroj: vlastné spracovanie

\section{Strategické ciele perspektívy interných procesov}

Ako každý podnik, aj kúpele Vyšné Ružbachy chcú byt' silným konkurentom ostatným kúpel'om na Slovensku a v Európe a chcú byt' úspešným podnikom, ktorý napreduje. Tieto ciele sú dost' všeobecné a nemusí nám byt' úplne jasné, čo si pod týmito ciel'mi máme predstavit'. Preto sme pre perspektívu interných procesov vybrali 3 konkrétnejšie ciele, ktorých naplnenie by malo zároveň pomôct' splnit' ciele stanovené vo finančnej a zákazníckej perspektíve.

Tabul'ka 8: Strategické ciele perspektívy interných procesov

\begin{tabular}{|l|l|}
\hline Strategický ciel' & Popis ciel'a \\
\hline I1: Posilnit' inovačný proces & $\begin{array}{l}\text { Aplikovat' zlepšujúce návrhy od zamestnancov, inšpirovat' } \\
\text { sa zahraničnými inováciami }\end{array}$ \\
\hline I2: Zvýšit' produktivitu práce & $\begin{array}{l}\text { Len spokojní zamestnanci majú snahu zvyšovat' } \\
\text { svoju produktivitu práce, ktorá sa odrazí } \\
\text { v celkovom lepšení výsledkov spoločnosti }\end{array}$ \\
\hline I3: Zefektívnit' predaj & Ponúkat' nové netypické produkty (pobyty) a služby \\
\hline
\end{tabular}

Zdroj: vlastné spracovanie

Zamestnanci často prichádzajú s nápadmi ako zlepšit', urýchlit’ svoju prácu. Stáva sa však, že vedenie nie je otvorené možnosti, že zamestnanec bude prinášat' inovácie do podniku a tzv. „zlepšováky“ im nedovolí. Zamestnanci často vedia, čo by uvítali klienti, nakol'ko sú s nimi v kontakte viac ako vedenie podniku. Ak budú klienti spokojní s prácou zamestnancov, odrazí sa to aj na ich výkone. Produktové portfólio podniku Kúpele Vyšné Ružbachy, a.s. bolo v roku 2016 zúžené. Berieme ohl'ad na toto rozhodnutie a nenavrhujeme vedeniu rozširovat' portfólio. Myslíme si, že ktorýkol'vek produkt, pobyt, zo súčasnej ponuky sa dá oživit', obohatit' tak, že by bol bezkonkurenčný.

\section{Strategické ciele perspektívy učenia sa a rastu}

Najdôležitejšiu úlohu pri plnení stratégie podniku zohrávajú samotní zamestnanci podniku, preto je im venovaná perspektíva učenia sa a rastu. Za najdôležitejší strategický ciel' považujeme zvýšenie spokojnosti zamestnancov. Aj ked' je spokojnost' vel'mi individuálna, vždy sa nájde niekto menej a niekto viac spokojný. Dôležité pre každý jeden podnik je mat' čo najviac spokojných zamestnancov a snažit' sa plnit' ich reálne požiadavky. Len spokojný zamestnanec môže udržiavat' vysokú kvalitu služieb a prinášat' firme zisk. Aby boli zamestnanci spokojní je nevyhnutné vytvorit' prostredie, v ktorom sa im bude dobre pracovat', ktoré ich bude motivovat', dá im možnost' d’alšieho rozvoja. Práve preto sú d'alšími navrhovanými ciel'mi tejto perspektívy zvýšenie motivácie zamestnancov, možnost' osobnej angažovanosti zamestnancov a rozvíjanie vzdelávacieho systému. 
Tabul'ka 9: Strategické ciele perspektívy učenia sa a rastu

\begin{tabular}{|l|l|}
\hline Strategický ciel' & Popis ciel'a \\
\hline U1: Zvýšit' spokojnost' zamestnancov & $\begin{array}{l}\text { Zaistit' priebežný (raz mesačne) monitoring spokojnosti } \\
\text { zamestnancov formou dotazníkov }\end{array}$ \\
\hline $\begin{array}{l}\text { U2: Motivovat' zamestnancov a angažovat' ich do } \\
\text { inovačných procesov }\end{array}$ & $\begin{array}{l}\text { Finančne motivovat' a ohodnotit' aktívnych zamestnancov, } \\
\text { snažit' sa zvýšit' ich iniciatívu v inovačných procesoch }\end{array}$ \\
\hline U3: Rozvíjat' vzdelávací systém & $\begin{array}{l}\text { Zabezpečit' zamestnancom možnost' zvyšovat' svoju } \\
\text { kvalifikáciu, organizovat' vzdelávacie semináre priamo na } \\
\text { pracovisku }\end{array}$ \\
\hline
\end{tabular}

Zdroj: vlastné spracovanie

\section{Výber meradiel, stanovenie ciel'ových hodnôt a strategických akcií}

Po určení strategických ciel'ov a ich vzájomných vzt'ahov je potrebné vybrat' vhodné meradlá, ktorými možno overit' plnenie jednotlivých ciel'ov. Je dôležité, aby sa v koncepte nachádzali kvalitatívne aj kvantitatívne meradlá. Strategický ciel je úplne popísaný až po stanovení ciel'ových hodnôt jednotlivých meradiel. Tieto hodnoty by mali byt' reálne a dostatočne ambiciózne. To je dôvod, prečo by mali byt' určené s ohl'adom na východiskovú úroveň (súčasnú hodnotu). V prípade meradiel, ktoré ešte neboli sledované, je vhodné ciel'ovú hodnotu odhadnút' a po určitom čase sledovania ju upravit'. Ku každému strategickému ciel'u v jednotlivých perspektívach sú navrhnuté aj strategické akcie, ktoré predstavujú spôsob ako zrealizovat' dané strategické ciele v podnikovej praxi.

\section{Meradlá finančnej perspektívy}

Tabul'ka 10: Meradlá finančnej perspektívy

\begin{tabular}{|l|l|l|r|r|}
\hline Strategický ciel' & Meradlo & Jednotka & $\begin{array}{l}\text { Súčasná } \\
\text { hodnota }\end{array}$ & $\begin{array}{l}\text { Budúca } \\
\text { hodnota }\end{array}$ \\
\hline F1: Znížit' náklady & $\begin{array}{l}\text { Celkové náklady na hospodársku } \\
\text { činnost' }\end{array}$ & $€$ & 3277971 & 3000000 \\
\hline F2: Zvýšit' obrat & Tržby & $€$ & 3280226 & 4000000 \\
\hline $\begin{array}{l}\text { F3: Zlepšit' celkový finančný stav } \\
\text { podniku }\end{array}$ & Výsledok hospodárenia & $€$ & -8082 & Zisk \\
\hline
\end{tabular}

Zdroj: vlastné spracovanie

\section{Navrhované strategické akcie:}

- F1 - Identifikovat' neefektívne využívanie zdrojov, odstránit' neefektívne činnosti.

- F2 - Zvýšit počet prenocovaní a prilákat' nových zákazníkov, hlavne komerčnú klientelu.

- F3 - Splnením strategických ciel'ov F1 a F2 sa zlepší celkový finančný ciel' podniku a bude splnený strategický ciel' F3.

\section{Meradlá zákazníckej perspektívy}

Tabul'ka 11: Meradlá zákazníckej perspektívy

\begin{tabular}{|l|l|l|l|l|}
\hline Strategický ciel' & Meradlo & Jednotka & Súčasná hodnota & $\begin{array}{l}\text { Budúca } \\
\text { hodnota }\end{array}$ \\
\hline $\begin{array}{l}\text { Z1: Zvýšit' kvalitu poskytovaných } \\
\text { služieb a modernizovat' kúpele }\end{array}$ & Dotazník spokojnosti & $\begin{array}{l}\text { Známka 1-5 (1 } \\
\text { najlepšie, 5 } \\
\text { najhoršie) }\end{array}$ & Žiadna adekvátna & 2,5 \\
\hline Z2: Získat' nových zákazníkov & Počet prenocovaní & Počet nocí & 86802 & 100000 \\
\hline $\begin{array}{l}\text { Z3: Rozšírenie on-line } \\
\text { marketingovej reklamy }\end{array}$ & $\begin{array}{l}\text { Počet zhliadnutí } \\
\text { reklamy na sociálnej } \\
\text { sieti }\end{array}$ & Počet užívatel’ov & $\begin{array}{l}\text { V súčasnosti nie je } \\
\text { v záujme podniku }\end{array}$ & $\begin{array}{l}\text { Viac ako } \\
10000\end{array}$ \\
\hline
\end{tabular}

Zdroj: vlastné spracovanie

\section{Navrhované strategické akcie:}

- Z1 - Investovat' do nových a lepších zariadení a vybavenia kúpel'ov, modernizovat' prostredie, v ktorom sa zákazníci počas pobytu pohybujú - bývajú, stravujú sa, trávia vol’ný čas. 
- Z2 - Vytvorením produktu, ktorý u konkurencie zákazníci nenájdu, zavedenie výhodného vernostného programu.

- Z Z3 - Venovat' sa on-line stránke na sociálnej sieti, publikovat' a propagovat' príspevky.

\section{Meradlá perspektívy interných procesov}

Tabul'ka 12: Meradlá perspektívy interných procesov

\begin{tabular}{|c|c|c|c|c|}
\hline Strategický ciel’ & Meradlo & Jednotka & $\begin{array}{l}\text { Súčasná } \\
\text { hodnota }\end{array}$ & $\begin{array}{l}\text { Budúca } \\
\text { hodnota }\end{array}$ \\
\hline $\begin{array}{l}\text { I1: Posilnit' inovačný } \\
\text { proces }\end{array}$ & Počet realizovaných inovačných nápadov & Počet & $\begin{array}{l}\text { Nebolo } \\
\text { merané }\end{array}$ & 25 \\
\hline $\begin{array}{l}\text { I2: Zvýšit' } \\
\text { produktivitu práce }\end{array}$ & $\begin{array}{l}\text { Výnosy / počet } \\
\text { zamestnancov }\end{array}$ & $€$ & 28461,03 & 50000 \\
\hline $\begin{array}{l}\text { I3: Zefektívnit' } \\
\text { predaj }\end{array}$ & $\begin{array}{l}\text { Tržby z predaja produktov na základe online } \\
\text { marketingovej reklamy na sociálnej sieti }\end{array}$ & $€$ & $\begin{array}{l}\text { Nebolo } \\
\text { merané }\end{array}$ & 100000 \\
\hline
\end{tabular}

Zdroj: vlastné spracovanie

\section{Navrhované strategické akcie:}

- I1 - Zabezpečit' vyhodnotenie inovačných návrhov od zamestnancov a realizáciu tých najlepších návrhov. Po implementácií návrhov sledovat' ich skutočný prínos pre spoločnost'.

- I2 - Motivovat' zamestnancov k hl'adaniu potenciálnych zákazníkov a tým zvyšovat' výnosy.

- I3 - Zaviest' nové predajné kanály, novú formu reklamy, nové produkty.

\section{Meradlá perspektívy učenia sa a rastu}

Tabul'ka 13: Meradlá perspektívy učenia sa a rastu

\begin{tabular}{|l|l|l|l|r|}
\hline Strategický ciel' & Meradlo & Jednotka & $\begin{array}{l}\text { Súčasná } \\
\text { hodnota }\end{array}$ & $\begin{array}{l}\text { Budúca } \\
\text { hodnota }\end{array}$ \\
\hline $\begin{array}{l}\text { U1: Zvýšit' spokojnost' } \\
\text { zamestnancov }\end{array}$ & Dotazník spokojnosti & $\begin{array}{l}\text { Známka 1-5 (1 } \\
\text { najlepšie, 5 najhoršie) }\end{array}$ & $\begin{array}{l}\text { Nebolo } \\
\text { merané }\end{array}$ & 2 \\
\hline $\begin{array}{l}\text { U2: Motivovat' a angažovat' } \\
\text { zamestnancov v inovačnom } \\
\text { procese }\end{array}$ & $\begin{array}{l}\text { Počet inovácíi navrhnutých } \\
\text { zamestnancami }\end{array}$ & Počet/Rok & $\begin{array}{l}\text { Nebolo } \\
\text { merané }\end{array}$ & 50 \\
\hline U3: Rozvíjat' vzdelávací systém & $\begin{array}{l}\text { Počet školení, ktorých sa } \\
\text { zamestnanci zúčastnia }\end{array}$ & Počet/Rok & $\begin{array}{l}\text { Nebolo } \\
\text { merané }\end{array}$ & 20 \\
\hline
\end{tabular}

Zdroj: vlastné spracovanie

\section{Navrhované strategické akcie:}

- U1 - Zabezpečit' pravidelný prieskum spokojnosti zamestnancov dotazníkovou formou. Na základe tohto prieskumu zavádzat' prípadné zmeny.

- U2 - Nastavit' ohodnotenie a mzdu zamestnancov tak, aby boli dostatočne motivovaní a zaviest' program na podporu iniciatívy zamestnancov.

- U3 - Viac investovat' do vzdelania zamestnancov. Nielen im schval'ovat' účast' na školeniach a preplácat' čast' nákladov, ale organizovat' školenia priamo v kúpel'och.

\section{Diskusia a záver}

Po vypracovaní finančnej analýzy spoločnosti Kúpele Vyšné Ružbachy, a.s. môžeme konštatovat', že finančná situácia podniku má zlepšujúca sa tendenciu. Ak bude tento trend v podniku pokračovat', $v$ nasledujúcich rokoch sa dostane do zisku. Na to, aby podnik napredoval, je však potrebných niekol'ko zmien. Navrhujeme manažmentu zamysliet' sa nad súčasným spôsobom merania výkonnosti, ktorý je zameraný na minulost' a hodnotí výhradne minulé ukazovatele. Pre úspech podniku v súčasnom ekonomickom prostredí je však dôležité brat' do úvahy aj ukazovatele zamerané na budúce výkony. Pokial' by sa podnik rozhodol pre implementáciu metódy BSC, jedným z hlavných prínosov by bolo komplexnejšie hodnotenie jeho výkonnosti. Za významný prínos považujeme najmä zaradenie ukazovatel'ov v perspektíve učenia sa a rastu. Úspech celého podniku začína spokojnými zamestnancami. Komunikácia 
medzi manažmentom a zamestnancami musí byt' na vysokej úrovni. Všetci zamestnanci podniku musia byt' priebežne informovaní o priebehu implementácie, plnení ciel'ov a o výsledkoch. Ďalším významným plusom by bolo presadenie vízie a stratégie spoločnosti do praxe. Štruktúra konceptu BSC umožňuje stanovit' ciele v nadväznosti na zvolenú stratégiu. Výhodou BSC je aj lepšia dostupnost' informácií o chode spoločnosti a jej nasledujúcom vývoji, jednoduchšie a prehl'adnejšie reporty. Ako posledné je nutné zdôraznit', že samotným vytvorením a zavedením metódy BSC tento proces nekončí. Postupom času, s rozvojom podniku a zmenami v jeho okolí, sa menia aj faktory ovplyvňujúce stratégiu. Vybrané ciele a ich meradlá sa môžu po čase stat' neaktuálnymi. Preto manažment podniku nesmie zabudnút' model BSC ako aj stratégiu podniku pravidelne upravovat' $\mathrm{v}$ závislosti na aktuálnych podmienkach.

\section{Literatúra}

[1] BAIN\&COMPANY, 2017. Management Tools \&Trends. [online]. [vid. 25. apríl 2018]. Dostupné z: http://www.bain.com/publications/business-insights/management-tools-andtrends.aspx

[2] ELIAŠOVÁ, D., 2009. Slovenské kúpel'níctvo v 20. storočí. Bratislava: Vydavatel'stvo Ekonóm. ISBN 80-225-1687-2.

[3] GRASSEOVÁ, M. a kol., 2012. Analýza podniku v rukou manažera. 33 nejpoužívanejších metod strategického řízení, 2. vydání. Brno: BizBooks. ISBN 978-80-265-0032-2.

[4] VÝROČNÉ SPRÁVY 2015, 2016, Kúpele Vyšné Ružbachy

[5] KAPLAN, R. S. and D. P. NORTON, 2007. Balanced Scorecard: strategický systém merania výkonnosti podniku. 5. vydanie. Praha: Management Press. ISBN 978-80-7261$177-5$.

[6] KARABAŠOVÁ, L', 2010. Metodický postup pre aplikáciu Balanced scorecard do organizácie. [online]. [vid. 25. apríl 2018]. Dostupné z: http:// www.dominanta.sk/MetodikaBSC. pdf

[7] KOURDI, J., 2011. Podniková strategie. Brno: Edika. ISBN 978-80-251-2725-4.

[8] KRÁL, B., 2010. Manažerské účetnictví. Praha: Management Press. ISBN 978-80-7261217-8.

[9] KNÁPKOVÁ, A. a D. PAVELKOVÁ, 2010. Finanční analýza. Praha: Grada. ISBN 97880-247-3349-4.

[10] LESÁKOVÁ, L. and K. DUBCOVÁ, 2016. Knowledge and Use of the Balanced Scorecard Method. Procedia - Social and Behavioral Sciences, 230 (39-48) 